\title{
Competing for kayabo: gendered struggles for fish and livelihood on the shore of Lake Victoria
}

\author{
Modesta Medard ${ }^{1,2}$ (D) Han van Dijk ${ }^{2} \cdot$ Paul Hebinck ${ }^{2,3}$ \\ Received: 29 April 2018 / Accepted: 3 September 2019/Published online: 5 November 2019 \\ (C) The Author(s) 2019
}

\begin{abstract}
The dry-salted trade of Nile perch or kayabo is important for many along the shores of Lake Victoria. The kayabo trade started in the 1990s and has been increasingly restructured due to changing regional and global trade relationships. This shift has led to the emergence of hierarchical trading relations, which create an exploitative network in which powerful middlemen control the access of trade for women from the Democratic Republic of Congo (DRC) and marginalizes the Tanzanian women, changing the organization from a poly-centric to a more centralized trade organization in the hands of a small group of powerful business men. We show in this paper that whereas the women traders from the DRC manoeuvred themselves in positions from which they could manipulate the network through bribery and conniving to derive substantial capital gains from the kayabo trade, their Tanzanian counterparts however are excluded from the decision-making processes, access to fish resources, financial capital, and negotiation power. They persevere by operating in increasingly competitive markets, relying on illegal fish that they sell with little profit at local and domestic markets. They survive in jobs that are insecure and risky by nature.
\end{abstract}

Keywords Gender $\cdot$ Networks $\cdot$ Fish trade $\cdot$ Markets $\cdot$ Lake Victoria

\section{Introduction}

The Nile perch (Lates niloticus) fishing economy offers many people in and around Lake Victoria opportunities to make a living, as fishers, traders, brokers, processors, workers, drivers, or controllers. The fishing sector dramatically changed during the 1950s when a formidable predator was introduced in the Lake: the Nile perch. The specie was introduced to more efficiently exploit the Lake's fish resources and is since a significant driver of change in Lake Victoria's

Modesta Medard

modesta_medard@yahoo.co.uk

Han van Dijk

han.vandijk@wur.nl

Paul Hebinck

paul.hebinck@wur.nl

Independent Consultant, Mwanza, Tanzania

2 Sociology of Development and Change, Wageningen University, Wageningen, Netherlands

3 Department of Agricultural Economics and Rural Extension, University of Fort Hare, Alice, South Africa fisheries. Before its introduction, the fishing economy was based on two endemic species of Tilapia and over 500 species of Haplochromis (Seehausen 1996) which, together, made up $80 \%$ of the fish biomass in the lake (Kudhongania and Cordone 1974). This impressive species diversity reduced substantially (Goldschmidt 1998). The emerging Nile perch fisheries also contributed to the reorientation of barter and local market-oriented economy to one that is increasingly shaped by global market demands for Nile perch but also for Tilapia and even indigenous species like dagaa which is a small sardine-like fish (Rastineobola argentia) and Haplochromines spp. (Haplos). Since the turn of this century, the Nile perch boom faded because of a combination of decreasing catches because of over-investment and over-fishing, use of illegal fishing gears (Medard et al. 2015; LVFO/EAC 2017), and decreasing global demand for Nile perch. The processes worked against the fishing sector as a whole that has become dominated by one or two species only. The restructuring that occurred in the wake of these developments, however, also resulted in the creation of markets for byproducts such as the sun-dried and salted Nile perch known locally as kayabo. When Nile perch is processed in this way, it has a shelf life of more than a year, as long as it is properly salted and conditions are not too humid. Kayabo is processed 
on the beaches and provides employment and livelihood opportunities for many people, including many women. Kayabo processing involves removing the fishes' guts, swim-bladder, and scales, before salting. A high proportion of the catch available for this method of artisanal processing is fish that is rejected by the export processing factories as being too small or of poor quality. The transformation of Nile perch into kayabo has led to more trading opportunities, specifically for women traders that came to the wider Lake area to begin to trade fish and other commodities. Not only local woman traders from around the Lake but also women traders from DRC began to trade kayabo. Access to, and control over, the fish trade and networks fundamentally changed as the expanded trade opportunities almost simultaneously stimulated increased competition for these products that are destined for various regional and domestic markets (Medard et al. 2015).

Our paper deals with the changes that have occurred in the fishing sector and kayabo trade business in particular. We highlight and problematize three major changes. First of all, trading became more hierarchical. The trade network gradually transformed into a vertically, mono-centrically organized, exploitative network of relations between trade actors. Secondly, the changes we observe in the fishing sector in and around Lake Victoria did not or hardly affected the gender roles and positions. The now mono-centred sector remains rather differentiated according to gender and gender roles. Men in their capacity of fisher, brokers, and distributors (continue to) dominate and occupy key positions of power from which they can control the sector. Women predominantly operate as retail traders for local domestic and regional markets and as processers (e.g. drying) of fish. Thirdly, when analysing the role of women and how they operate in the fishery sector, we need to differentiate between them. Some women traders managed to access and that could afford to invest substantial amounts of capital which allowed them to access large quantities of kayabo and hence to successfully and securely trade in kayabo. The women that were not able to rally enough capital find themselves in less prominent and even marginalized positions, continuously struggling for survival. It was the women traders from the Democratic Republic of Congo (DRC) that managed to capture the kayabo trade leaving the local Tanzanian women traders to trade in small quantities and also illegal fishing.

The article aims to unpack these dynamics and explain why and how local Tanzanian women traders have over time been manoeuvred in marginal positions. This necessitates analysing the relationships between male businessmen and the women traders from DRC as well as traders from Tanzania. Our analysis takes the form of a network analysis of the kayabo trade within which we pay special attention to gender relations, roles, and positions. We make use of case study material of the kayabo fish trade in the Kirumba market in Mwanza, a town close to the shores of Lake Victoria in north-west Tanzania (Fig. 1).
The paper proceeds as follows. We first explain the theoretical frame for our analysis. This is followed by a short explanation of how we selected the informants for our research. The section that follows expounds the historical context, and notably the changes that have taken place in the Lake Victoria fisheries and economy. We then zoom in on the Kirumba market which is the central place where most of the action in terms of trading, networking, and struggles over kayabo take place. The two sections that follow present our main findings of the study and explain the processes that structure these findings. We first elaborate how women traders from the DRC manage to become the predominant actor in the kayabo trade and thus how they manage to survive in a domain that is largely controlled by few businessmen. The section that follows zooms in on the marginalizing position of local Tanzanian women traders. In the concluding section, we tie it together.

\section{Gender, fishing, and markets: perspectives, concepts, and methods}

Our paper combines a network approach with a gender perspective of the nature of the social relationships and negotiations between the genders. A social network approach is a powerful tool to analyse the collaborations and relations between, and amongst, groups of traders and their social embeddedness as individuals (Murdoch 2001; Schnegg and Lang 2002; Mitchell 1974; Long 1972). Networks display the exercising of control and regulating of social and economic activities. Roberts (1994:8) points out that 'the issue is not one of regulation per se but of the form of regulation.' Our task here is thus to analyse and document how regulation is exercised, by whom and which strategies are employed. We specifically draw on Mitchel's (Mitchell 1974) extremely useful classic approach to the analysis of networks, which hinges on investigating and documenting the nature and frequency of contacts between actors and where nodes emerge. The nodes signify where the power in and over the networks concentrates and becomes most manifest.

The trade networks we analyse here, we argue, are structured by relations of power between the genders, with men and women performing different roles within the network. Men, who are the brokers in most cases, and relevant for our case, the different kinds of women traders from Tanzania and DRC develop and maintain relations with each other and engage in negotiations to gain access to kayabo and export permits. The women traders operate as women but are socially differentiated as they operate from different societal positions providing them with differentiated opportunities to engage with the specificities of the trade network. Mapping these contacts and connections shows which actors occupy central places in a network which gives them the ability to exercise power and influence outcomes. The fewer the nodes, the more 
Fig. 1 Lake Victoria showing international boundaries, regions, and districts
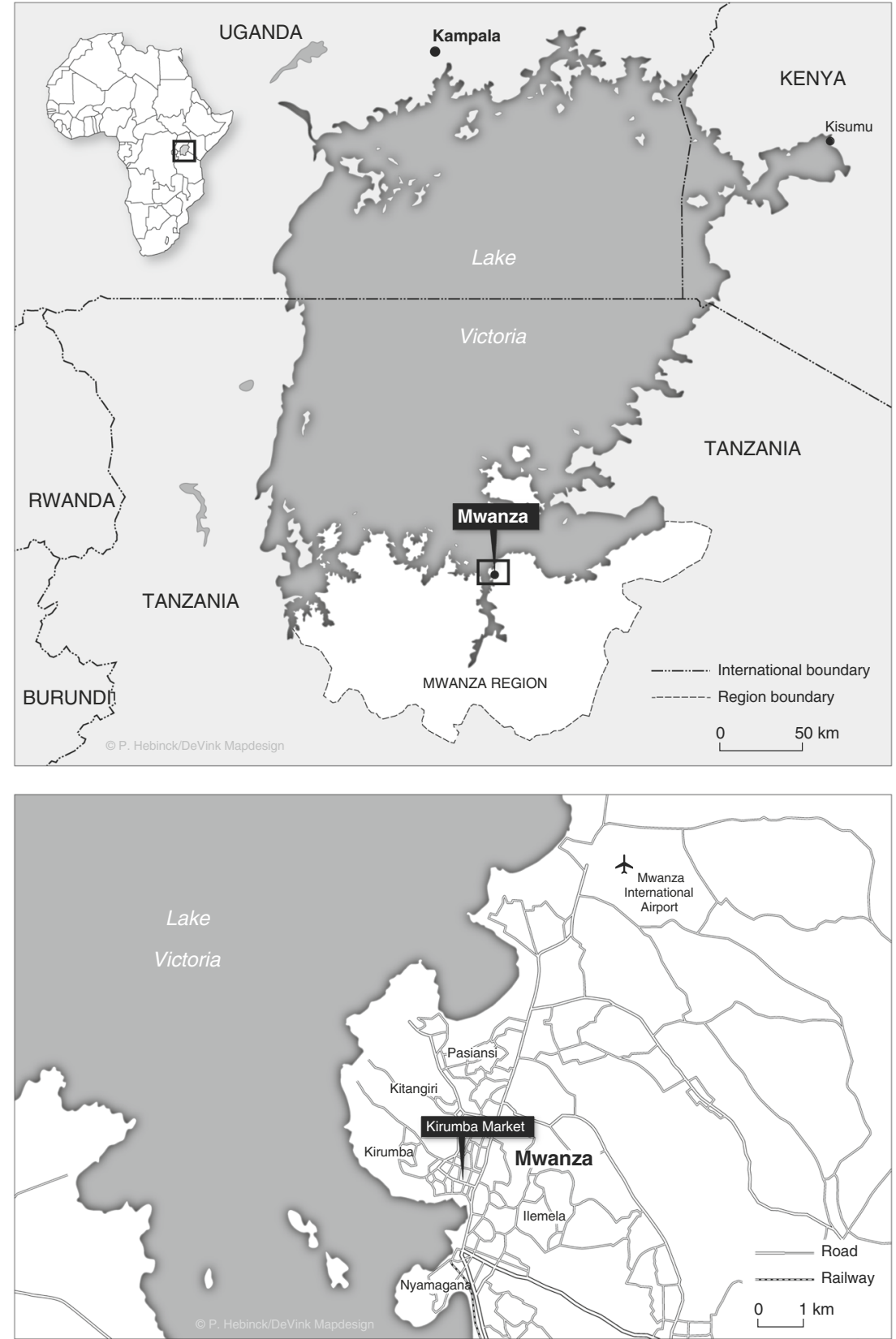

the network becomes mono-centrically organized (Ostrom 1990), the more regulatory power is concentrated in the hands of a limited number of actors (Mitchell 1974). The concentration of power gives rise to more inequalities within the network. The inequalities that emerge when power becomes concentrated is often associated with gender-specific roles and societal positions (see for example Handschuch and Wollni 2016; Bradford and Katikiro 2019). The concentration of power into few hands, however, does not occur without resistance, social struggle, or negotiations (Long 2001, 2008; see also Scott 1985).

The negotiations and struggles that take place between the social actors in the network can be observed at different sites and localities in and around Kirumba market and on the beaches and fishing camps. These are the sites where women fish traders, both local and from DRC, are struggling (in different ways) to access the lake's resources to feed their families, educate their children, and gain economic independence. The strategies they devise to achieve that crucially involve agency - the ability to change, persist, resist, accept, or challenge the social framework and networks in which they find themselves (Long 2001). They are most evident where the inequalities over access to resources, and particularly those based on gender, are most pronounced and where the nodes in the network are controlled by a few individuals. These 
gender imbalances are embedded in (formal and informal) institutions, such as social networks, political connections, and distribution networks and define how women and men are incorporated within those networks and, thus, their scope for making choices.

The premise of gender analysis is that women and men are positioned differently in society because of their gender. Gender plays an integral role in structuring societies, economies, political systems, and everyday experiences (Moore 1988; Scott 1992). Many gender studies highlight how female and male genders are differentially constructed, contrasting the two. Power and also resistance plays a central role in this construction (Skaptadóttir 1998). It is also generally accepted that gender studies should pay attention to differences amongst women (Mills 1995; Moore 1994) as gender and gender relations are constructed through everyday practices and strategies and are subject to change. This can give some women a superior status whilst victimizing others (Medard 2012) or casting them in the role of bearers of tradition. Gender differences and inequalities are embedded in social institutions, networks, and in access to resources, which differ from place to place and time to time (Bradford and Katikiro 2019). Frangoudes and Gerrard (2018) also remind us that these varied configurations of gender, culture, ethnicity, identity, and economic processes lead men and women to adopt different livelihood strategies and lifestyles.

In the fishing economy around Lake Victoria, men and women perform complementary roles, with the men mostly fishing and the women marketing and processing the fish (Medard et al. 2015). The economic transactions between fishermen, camp owners, and women traders in Lake Victoria often involve sexual relations. 'Fish for sex' is a common practice in and around Lake Victoria which has already been well documented (Béné and Merten 2008; Lowen 2014; Medard 2012, 2015; Lwenya and Yongo 2012). Women engage in sexual relations in the hope of taking back a prized catch which they can dry and take to market. The 'fish for sex' relations can be interpreted as an opportunistic act that allows manipulating the trade and deriving favours from influential men in sexual relations. Whilst as we will show in our case study, this may apply to specific group women traders, 'fish for sex', however, also manifests women's subordinate position in the fish trade. These are the women that in most cases are socially and economically marginalized and their livelihoods contain risky and insecure components (Medard 2012; Lwenya and Yongo 2012).

Apart from being fishermen, men also perform the role of brokers and, as such, have managed to manoeuvre themselves into strategic and powerful positions, controlling kayabo operations. This is particularly so since the trade has evolved from one dominated by export processing factories, to one in which local and regional demand plays a greater role. Most of these brokers hail from Mwanza town. Local women traders are not able to compete with men in the fish trading and processing chain, so they depend on a weak and fluid network of brokers, which perpetuate the relationships of male dominance and female subordination. At the same time, their position is challenged by women traders from DRC. They have established for themselves a strategic niche within the local fish trade, increasingly squeezing local women to the margins of the fish trade. Overall, there is increasing competition between different categories of traders often organized in networks based on identity categories, such as nationality and gender.

The regionalization of the kayabo trade has, we argue, led it to evolve from a poly-centred and loosely coordinated decisionmaking network into one where power is concentrated in a few hands: those of the male brokers, with power shifting in favour of Congolese women traders. This shift, together with the increased capacity to fish, has increased competition and has turned Lake Victoria into a highly contested space where women struggle for opportunities to improve their families' wellbeing (Medard et al. 2015). Access defined as the 'ability to benefit from' (Ribot and Peluso 2003) and specifically the capital means to access fish has evolved as the key issue here and is embedded in relations of power, in which specific categories of people control and monitor others' possibilities to participate in trading networks (see also Ribot 1998). When there is unequal access, some people can control the access of others by virtue of occupying a position of power; those that occupy subordinate positions have to invest resources in developing social relations to achieve or maintain access (see Ribot and Peluso 2003). Gender, age, and ethnicity often play important roles in defining peoples' ability to negotiate access to resources and who (or which groups) benefit(s) the most from their participation in the network. Ensminger (1992) argued that networks that are founded upon shared identities (e.g. ethnicity, race) and interests consolidate existing power relations which in turn strengthen the network and its connections. Not only Tassi (2017) but also Long (1972) are well-analysed accounts of similar processes. However, the argument we put forward here is on the one hand that changes in trade flows, in resource availability or processing techniques potentially reconfigure networks in ways that lead to the exclusion of some categories of actors and the dominance of others. On the other hand, networks are also reconfigured when certain network actors can manipulate the network rules and thus the mode of network regulating.

\section{Methods}

Our study sets out to depict the kayabo trade as well as showing how gender is constructed and negotiated in daily life in the localities of Kirumba's fish market. We made use of a network approach to order and to analyse our data from interviews, observations, and written sources to explore how genderbased control to access and to trading opportunities are organized and experienced. We conducted fieldwork in 2009-2010 
at Kirumba market where kayabo is collected, traded, and transported (Fig. 1). We revisited the Kirumba market in 2017 to interview several key informants again. The selection of respondents was done at the Kirumba market hub after defining and analysing the actor's categories in the trade and distribution networks. We drew on local social networks to access groups of people as well as individuals willing to participate in the interviews. Both random and purposive sampling was used in selecting participants. A degree of randomisation was applied in the Focus Group Discussions (FGDs) to reduce selection bias inherent in some forms of personal recruitment. During the FGDs, we purposively selected individuals for face-to-face interviews based on their knowledge, ability to articulate issues, uniqueness of their response, experience, and willingness to participate. Others were selected through snowballing. The interviews were partly structured by using a pre-prepared list of questions and partly un-structured by letting the participants freely talk about their involvement in the kayabo trade. This interview was done with 10 local female traders, four male Kirumba cooperative leaders, four male kayabo brokers, three male truck drivers and brokers, and 15 DRC kayabo traders of which 10 were female and five male. We also conducted seven in-depth interviews with 11 key informants selected purposively and randomly. Participant observations of interactions between the different actors provided important insights that added details by actively involved in offloading kayabo cargos arrived from islands, sorting, buying kayabo, eating kayabo meals, and accompanying key informants to food stalls and other activities. Quantitative data was collected on tonnes of kayabo, prices, and number of kayabo traders at Kirumba market. The data were combined, calibrated, and triangulated to better understand and describe the actors and market processes at play in market entry strategies, negotiating prices, purchasing, handling, and transportation (see also Saunders et al. 2009: 152). In 2017, the follow-up research was done in Kirumba to validate some of the information collected earlier through participant observation and individual interviews.

Our interviews were designed to interrogate six main themes: (1) the organization of the kayabo trade at the Kirumba market, (2) how traders have responded to increasing competition, (3) the decision-making process (how and who) related to the trade and distribution of kayabo, (4) recent changes to kayabo and other Nile perch products, (5) how gender and gender relations, social identity/nationality and economic processes have shaped the kayabo markets and local practices, and (6) how the trading relations differ between local women and those from DRC.

\section{Historical trends of the fishing industry and trade in Lake Victoria, Tanzania}

In Lake Victoria, access to resources and fishing and trading arrangements are mostly vested in the large groups that control access to the local, regional, and export market channels. Lake Victoria's fishing landscape is a hybrid one, influenced and shaped by the complex interactions between the Lake's many peoples and their interactions with the outside world (Medard et al. 2014; Medard et al. 2015). Over time, this landscape has gone through several dramatic transformations. New sets and categories of social actors have entered the trade and now interact, collaborate, and compete with those who historically relied on the lake for their livelihood (e.g. local women, fishers and their families, community members, and local traders). The new actors are usually foreign owners of fresh and frozen Nile perch export processing factories, regional traders of sundried dagaa and kayabo, middlemen, fish handlers, traders, truck drivers, fish brokers, and truck brokers. During the early 1990s, the market conditions for Nile perch in and around Lake Victoria changed fundamentally when two big fish processing factories from Kenya opened subsidiaries in Tanzania. Before then, fishermen sold their fish through Tanzanian businessmen who worked as local agents and brokers who were provided with motorized boats for collecting the catch, which was transferred into vans and insulated trucks operated by export processing factories (Medard et al. 2015:98).

By 2003-2004, the number of Nile perch export processing factories in Tanzania and the neighbouring countries Kenya and Uganda reached a peak of around 35-40. Since then, the volume of fish and fishery exports from Lake Victoria has only decreased. Between 2005 and 2015, the metric tonnage of Nile perch exports dropped by $51 \%$ in Tanzania, $55 \%$ in Uganda, and 89\% in Kenya (LVFO/EAC 2017). This decrease is the result of increased fishing efforts and the decline in the number of Nile perch that meet the fillet size requirements for intercontinental export $\left(50-85 \mathrm{~cm}^{1}\right)$. To address this situation and to tackle the problem of illegal fishing, measures were imposed to control minimum mesh sizes for gill nets, slot sizes for Nile perch, and the minimum size of Tilapia. These measures did not, however, help to improve the Nile perch catch (Mkumbo 2012:9). In consequence, some 23 factories have been closed in recent years. ${ }^{2}$ The combined effect of the closure of export processing factories and the reduced volume of Nile perch catch has intensified the competition between the export processing factories and regional and local traders in all market tiers.

The decline of intercontinental exports and growing competition of fish has triggered the emergence of two, structurally differently organized trade and processing networks of

\footnotetext{
${ }^{1}$ In Lake Victoria, fishers are allowed to fish Nile perch with slot size of 55$85 \mathrm{~cm}$ total length (TL) to protect immature fish, to harvest mature individuals and, at the same time, to protect the large females which are expected to replenish stocks. Small slot size is below $55 \mathrm{~cm}$.

2 Tanzania currently has 13 Nile perch export processing factories of which only eight are operational. In Kenya, just two out of nine factories are operational and Uganda has seven operational factories, compared with 18 previously.
} 
Nile perch. The first network hinges on the trade in domestic and regional markets of kayabo. The processing and trading of kayabo rely heavily on the Nile perch that is rejected by the export processing factories. The fortunes of the actors in the kayabo trade thus largely depend on the dynamics of the Nile perch sector which in turn are deeply influenced by global and regional market forces. A second off-spring is the growing number of cold store companies who trade frozen Nile perch on domestic and regional markets (Medard et al. 2015), mainly to meet the growing demand amongst the region's middle classes. This has led Mwanza to become the hub of a network of small and medium traders and distributors. These cold store companies compete with the well-established export processing factories for fish supplies. One way in which they compete is by renting out refrigerated storage to small and medium distributors, a service not provided by the export processing factories. Overall, there has been a drastic change in the Lake Victoria fish economy with men gaining control of fishing, the fish trade and distribution networks (Hofmann 2011; Medard 2012, 2015; Lwenya and Yongo 2012; Medard et al. 2014). Men now make up by far the majority by approximately $65 \%$. This certainly became the trend when Nile perch became a major export commodity (Medard 2012:556). Ironically, this control became more pronounced after the lake's resources became connected to regional and global markets.

\section{The kayabo trade at Kirumba}

Kirumba plays a strategic role in Lake Victoria's fishing economy. 'Kirumba' is a greeting word in Ki-Sukuma, which means 'thanks' (or 'asante' in Ki-Swahili). It is the main trading place from which kayabo and dagaa are being traded for domestic and export markets. Kirumba is also the place where the by-products of Nile perch from the export processing factories are being handled: fish frames (skeletons), belly flaps, skin, fins, fish offal, fish heads, spoiled whole fish, spoiled fillets, and offcuts. It is also the name of a market in Tanzania that is well-known for dagaa and kayabo and it is also a gathering and networking place for local and foreign traders and their local business aides.

In the early 1970s, Kirumba was dominated by Sukuma and Arab traders who had their associations based on ethnic affiliation. This was also the time of Ujamaa when the farmers' cooperative societies' movement gained ground in Tanzania to form the backbone of a new type of rural economy (Raikes 1975; Hyden 1975). The first cooperative society for marketing fish and other foodstuffs was launched at Kirumba market in 1978. In the years after the establishment of export processing factories (between 1991 and 2003), nine more cooperative societies were formed that dealt with dagaa and a variety of Nile perch products, namely, fresh, smoked, drysalted and by-products from export processing factories (Medard 2003). Since then, Kirumba was organisationally transformed and became a regional and international market for dried fish, mainly kayabo and dagaa. The cooperatives that mostly handled these products were all headed by men.

To date, the export of kayabo to the Great Lakes region has increased enormously to dimensions unprecedented for freshwater fisheries in Africa. The expansion of the Nile perch export meant that the Kirumba market needed to be reorganized and refurbished to meet international standards (Medard et al. 2016) and to reduce post-harvest losses. By the end of 2005, the new market had been reconstructed. When Kirumba re-opened, local women lost visibility and business space:

When this market was modernized, with concrete slabs for displaying fish, modern toilets, fish stores, electricity, water, concrete walls and offices, we were excluded. The scale of operations, capital investment, leadership and a highly organized modernized market were the priorities for Mwanza city council, the market's owner. Since then we have sold our small fishes on the ground down at the edge of the market wall and often have to resort to hawking in town and along the streets. We have no presence in this market and this limits our business (Tabia Masanja, pers. comm. October 2010).

Tabia's narrative and other narratives we collected show that the main challenge for local women is organizational and negotiation power. They were not able to initiate change or to find a space where they could influence decision-making about the operation of the market. They were at the receiving end of management policies and their voices were disregarded.

Although women have very little control of the fisheries, they are connected to the industry in other strategic ways. These are interlinked with their daily life practices, their sense of identity, and the social structures (groups and networks) of which individual women are apart. Local women confirmed in the focus group discussions held in Kirumba in 2010 that they had to work hard to devise strategies that can make their lives better and that fit with the structures imposed by local and global trade (Medard et al. 2015). Whilst this is true for most local women traders at Kirumba, a group of women traders from the DRC that established their trading businesses here have managed to manoeuvre themselves into positions of power in the kayabo business. They capitalized on their business networks in the DRC to open up new markets in the DRC for kayabo and other products from the Lake. This has pushed local women in the fish trade to the margins and furthered their economic disenfranchisement. 


\section{Strategic and protected social networks: a driver of the trade in kayabo by DRC women}

One of the findings that stand out from our fieldwork and analysis is that some male businessmen and cooperative leaders at Kirumba operated as active intermediaries for female kayabo traders from the DRC. They provide them with a variety of services in return for cash and other, often sexual, favours. These businessmen and leaders of the Kirumba cooperative societies are very influential. Through providing credit and logistical support to traders, middlemen, and camp owners, they dominate the networks for procuring Nile perch from islands in Lake Victoria. Their strategic position in the kayabo trade network also allows them to influence the price of kayabo. In this way, they maintain control over the entire, or at least a large part, of the kayabo business in and around Lake Victoria. They also maintain frequent and close contacts with some government officials. This not only keeps their transaction costs low and make good profits from the kayabo and dagaa trade. There is evidence that they manage to evade paying taxes (Medard et al. 2015: 216). Tax collection was at the time subcontracted to a rich trader and the more taxes he collected and paid to the city council, the greater his commis$\operatorname{sion}^{3}$ (Medard et al. 2015:114). There is also evidence of them falsifying the amount of kayabo landed and they are also implicated in black market currency exchanges.

These businessmen also ensure the security of DRC women traders whilst they are in transit, at landing sites or Kirumba's market and have a convenient sideline in owning the guesthouses that are frequented by DRC traders. These were not only rumours; three respondents confirmed these rumours loud and clear in interviews. One female DRC trader pointed out that:

It is not possible to operate this business in a foreign country. The demand for fish is so high with a lot of interest from government and non-government actors. Immigration, police, revenue authority, fisheries, city councils, local administration, fish brokers, truck brokers, fish collectors and aiders, export industrial processors and local and regional traders. You have to know official and unofficial logistics and complexities. As foreigners, we have hosts to do on our behalf (Anonymous 21/10/2010).

These networks are the product of business relationships built over a longer period of time through good communications, common interests, ability to keep business secrets, and business relations that are embedded in sexual relations. These connections have often been forged and maintained through

${ }^{3}$ In 2010, the Mwanza City Council received about TShs. 46.6 million (US\$ 29,125 ) in taxes every month from the Kirumba market. mutual trust, ethnicity, friendship, and kinship. As a result, over time, the control and power over the kayabo trade have shifted from a multitude of mechanisms of coordination and decision-making into a few hands. One local woman respondent remarked that:

We have one market appropriator, a rich man. He has been contracted by the city council to collect taxes in this market; he owns guest houses, rental houses and an unofficial bureau de change. He controls the leaders of the cooperative societies and thus their members. He lends money to cooperatives and individuals. He is in control because he makes loans to many people whose survival depends on these loans (Anonymous 21/10/ 2010).

To show how such networks operate, we will depict how a group of 33 DRC kayabo women traders are protected by a network of strategically placed rich businessmen and traders. Our focus on these traders and their interconnections are legitimized by the key role they played in the transformation of kayabo trade. They are an aggressive, opportunistic, and risktaking group of traders who have shown resourcefulness in identifying ways to access kayabo, strategically tapping into existing networks using discursive and non-discursive means, including sexual favours.

DRC women traders travel to various islands and landing sites 'illegally' (that is without a valid export permit) as foreign traders to purchase kayabo and fresh Nile perch for further processing. They are accompanied by an aide, a member of a cooperative society from Kirumba, in possession of a collective cooperative trading licence and identity. Whilst the funds are kept by the women, the negotiations, purchases, processing, labelling, and transportation to Kirumba take place under the name of the aide. Whilst on the islands, his task is to hire labourers for processing the kayabo, to arrange the necessary administrative papers, to negotiate labour costs, and to fix the fish prices. They also protect the woman against robbery, drowning, and any ill-treatment. The women usually stay for a week or two until their loads were assembled (normally 2000-3000 pieces, equivalent of 1.5-3 tones) and transported to Kirumba. The aide is remunerated a fixed commission of TShs.200,000-250,000 (\$133-166) per trip to cover his expenses. If any problems arose, his boss in Kirumba would try and bribe government officials.

The second component of the strategy of DRC female traders is to liaise with high-ranked and well-situated brokers. They are particularly drawn to those brokers who virtually control the many Nile perch fishing camps on the Lake's islands. These brokers purchase between 2.5-3 t per trip and can earn around TShs. 15,000,000-20,000,000 (U\$ 10,000$13,500)$ per trip for purchasing kayabo often achieving margins of TShs. 100-400 for each fish. These traders also make 
use of the Kirumba cooperative society's trading permits to register all transactions from the islands to Kirumba and border towns. An interview with a cooperative leader at Kirumba revealed that the relationship between DRC women and highranked brokers in this arrangement went beyond just business.

These women have more than one business because getting tonnes of Kayabo is risky and you need to be aggressive and take risks. They have brokers who network with fishing camps, illegal operators and the agents of fish factories. When the brokers come back from islands they eat and drink with these women and abandon their wives because of money and sexual affairs. The women feel that through sex, their relationship with brokers is reinforced as they give them a lot of money to buy fish loads. Brokers also spend their commission buying beer and foodstuffs for women in their guest rooms (Kalisa Rajabu, 2010).

An interview with a female trader from DRC not only confirmed the narrative above. The majority of DRC women traders appear to hail from Kalemei and Bukavu. They were all married; the majority hailing from Lumbumbashi were single or divorced and therefore, they had the freedom to do business without interference from their male partners. They spent substantial time away from their families to earn money which could be read as underlining their independence from others such as their husbands and families. They also controlled substantial amounts of capital (see Table 1) compared with what local Tanzanian women traders could rely on for their trade (see Table 2). Braun (2019:378) also detailed that the highly mobile Congolese women had a different status than the local Tanzanian women traders. For them, travelling is structured by looking for opportunities for employment, food, and money and whilst searching for opportunities, they

Table 1 Average trading capital of female and male DRC traders

\begin{tabular}{llll}
\hline DRC locations/gender & $\begin{array}{l}\text { Number of } \\
\text { traders }\end{array}$ & $\begin{array}{l}\text { Capital in } \\
\text { US\$ }\end{array}$ & $\begin{array}{l}\text { Average capital per } \\
\text { trader in US } \$\end{array}$ \\
\hline 1. Kalemei & & \\
Male & 4 & 400,000 & 100,000 \\
Female & 8 & 400,000 & 50,000 \\
2. Kasai, Lumbumbashi, Likasi, and Kanaga & \\
Male & 4 & 800,000 & 200,000 \\
Female & 6 & 900,000 & 150,000 \\
3. Bukavu & & & \\
Male & 7 & 105,000 & 15,000 \\
Female & 19 & 85,500 & 4500 \\
Total & 48 & $2,690,500$ & 569,500 \\
\hline
\end{tabular}

Source: Trezoo Amin, leader of APOFREM, August 2017
Table 2 Average trading capital of local Tanzanian female and male traders

\begin{tabular}{llll}
\hline Market & $\begin{array}{l}\text { Number of } \\
\text { traders }\end{array}$ & $\begin{array}{l}\text { Range of capital } \\
\text { in US\$ }\end{array}$ & $\begin{array}{l}\text { Average capital } \\
\text { per trader }\end{array}$ \\
\hline Kirumba & & & \\
Male & 25 & $23-11,650$ & 330 \\
Female & 10 & $17-660$ & 45 \\
\hline
\end{tabular}

Source: own survey, October 2010

are not restricted by marital relationships. Congolese women with financial success are depicted as duplicitous women having affairs abroad and ruining their marriages (Braun 2019:386). Young single women, in particular, are portrayed as being extremely mobile. They did not remain in their homes but created networks outside their family to escape the patriarchal control (Pype 2010:212). These social networks served to mitigate the risks associated with the business; these included paying fines and bribes referred to as sucrés (sweets) (Braun 2019: 386).

A third strategy of the DRC women is buying kayabo from Kirumba's cooperative leaders. They place sizeable orders (several tonnes) and ask the cooperative leaders to arrange 2 or 3 'fish collectors' to organize loads in various islands whilst they remain at Kirumba. Nepotism, family relations and ethnicity, plays a big role in the selection of collectors, who are generally the relatives, friends, or fellow tribesmen of the cooperative leaders. The women traders display a deliberate strategy of commissioning two or more collectors, to stimulate competition amongst them. This also saves time and allows simultaneous purchases of large quantities from several locations. The collectors received commissions of between TShs. 200,000 and 300,000. Two collectors can collect 2000-3000 pieces $(2-3 \mathrm{t})$ in about 2 weeks.

Further discussions with DRC women traders confirmed that they also competed with men from the DRC for capital. Table 1 provides an overview of 15 male and 33 female traders from the DRC and their capital investments in kayabo trade. They are organized in what is known as the APOFREM association. APOFREM is a registered association of fish traders in the DRC. The women report accessing their capital from various sources such as friends, relatives, women groups, APOFREM, fabric business, jewellery business, and formal and informal micro-finance groups. DRC men, in contrast, convey to acquire funds from diverse but rather formally registered sources such as fish traders' association, formal banks, micro-finance groups, rental houses, wholesale and retail shops, jewellery business, renting out farms, and selling family properties such as cash and food crops, land, and cattle.

DRC women traders, however, also face difficulties and they spoke to us about their daily struggles with the scarcity of kayabo, high demand (thus competition) and rising prices. 
Prices have more than doubled or even tripled in the last few years. For instance, during 2009-2010, the price for an extralarge kayabo (15 kg or more) was between TShs. 70,000 and 150,000 (US\$ 47-100 when exchanged officially) and for a smaller size (of less than $2 \mathrm{~kg}$ ), it was between TShs. 6000 and 20,000 (US\$4-13). In October 2017, a 3-kg processed kayabo costed TShs. 50,000 (US\$ 22.5) at Kirumba market.

\section{Strategies of DRC women traders}

The DRC women traders deploy various strategies to ensure their strategic role the kayabo supply and fulfilling their loads. They divide themselves into two groups and alternate their trips to Kirumba. They also bring fabrics (vitenge) to Tanzania to sell them on the black market in Mwanza (thereby evading import taxes). To do their kayabo and fabric business, they arrive with US dollars which they convert on the black market into TShs. The black market exchange rate is almost double the official one (Medard et al. 2015:115). ${ }^{4}$

Another strategy they resort to was to purchase un-gutted Nile perch, which provided them with fish and fish maws (swim bladders). These maws have a very high market value in China.

When Nile Perch is sold you are asked if you want both the fish and its maw or just the fish. A gutted Nile Perch is cheaper than the whole Nile Perch because of the fish maws. Fish maws are in high demand and attract lucrative prices. We sell them to local Chinese factories (interview with Alizia Musimbwa, October 2010).

Accessing un-gutted Nile perch is not easy. Bribing the agents of export processing factories to reject fish of doubtful quality at the landing sites is a way to access these and to sell the maws separately. Selling fish maws in China or to Chine processors and traders is preferred because of the much higher process compared with the local markets. ${ }^{5}$

An interview with a retired fisheries officer revealed that the Fisheries Department created check-points in the border towns of Sota and Sirari (Mara), Kanyigo and Lusumo

\footnotetext{
${ }^{4}$ In 2010, the official exchange rate was 1US\$ for TShs. 1500 compared with 1 US\$ for TShs 2270 on Kirumba's black market.

${ }^{5}$ In 2009-2010, 10-kg fish maws bought at one of the beaches fetched TShs. 220,000 (US\$138) and $1.5 \mathrm{~kg}$ for TShs. 24,000 (US\$15) (Medard et al. 2015:101). In December 2017, $10 \mathrm{~kg}$ of fish maws bought in Mwanza town was priced about 5 times more (i.e. TShs 1000,000 (US\$ 450) and $1 \mathrm{~kg}$ TShs. 80,000 (US\$ 36)). Field inquiry from a local fish maws collector and trader in Mwanza learned that prices for fish maws in China and Hong Kong were estimated to be around 10 times higher (between about US $\$ 1500$ and US $\$ 350$, pers. Communication Richard Byabato 2010). A recent regional study on value chain analysis from Lake Victoria found that the international prices of dried maws per kilogramme range between US\$ 450 and US\$ 1000 depending on size, product quality, and market strength (GIZ and LVFO 2018:14).
}

(Kagera), Tunduma (Mbeya), and Kasumulo (Rukwa) in 2004 to try to thwart this illegal trade. These efforts were, however, circumvented.

I was stationed at Kirumba for recording and tracking fish trade and cargo destinations and to make sure the government records matched with traders' quantities and the amount of taxes paid. I noticed serious illpractices and called my boss to inform him of my observations to strengthen the central government's tax collections at Kirumba and the border stations. I told him how the government was losing taxes to foreign traders. Surprisingly he replied '.... you are stationed at Kirumba. Those in border towns know what they are there to do. Do your work, the rest will be taken care of at the border stations.......'. I think the boss had a personal interest in the trade (Name withheld, 28/8/ 2010).

DRC traders also conspire with brokers and rich traders to evade paying taxes and export fees to maximize their profit and increase their operating capital. Medard et al. (2015) reported that the tonnage of kayabo destined for export was frequently under-reported or not recorded at all at Kirumba. Kayabo was also labelled as 'domestic cargo' intended for border towns with the loads being offloaded overnight across the border. The traders made use of trade permits designed for domestic trade and paid a minimum of TShs. 5000 (US\$3) and a maximum of TShs. 50,000 (US\$33) ${ }^{6}$ needs to be paid for any domestic volume. Besides, some shipments of kayabo whose duty was $\$ 0.18$ per $\mathrm{kg}$ were documented as fish heads or fish frames and were levied $\$ 0.025$ or $\$ 0.009$ per kg.

An interview with the owner of a clearing and forwarding firm at Kirumba market revealed that the involvement of kayabo traders from DRC had made him redundant because kayabo was not being officially exported. The export routes in the documents were falsified with the truck release orders being documented to border towns, not as crossing the border to towns in DRC. ${ }^{7}$

The success of female traders from the DRC relies on a range of factors. This includes their ability to maintain relations with the brokers who control the networks with the islands. They also operate as a distinct group of traders, whose identity as foreigners offers the potential of more lucrative business opportunities. They can also communicate their business secrets in French or Lingala,

\footnotetext{
${ }^{6}$ The government levies for domestic trade are TShs 5000 for $101-1000 \mathrm{~kg}$, TShs 10,000 for $1001-5000 \mathrm{~kg}$, TShs 30,000 for $5001-9999 \mathrm{~kg}$, and TShs 50,000 for $10,000 \mathrm{~kg}$ or more (URT 2009).

${ }^{7}$ Gibbon (1997:44) pointed out that the market receipts books at Kirumba he had collected indicated that only 300 t of kayabo were sold for export in 1995, the figure which appeared to have little relationship to reality. Gibbon (1997) estimated that exports were more than $2000 \mathrm{t} / \mathrm{year}$. These underestimations were common and flagrant. For instance, fifty tones could be recorded as five tones.
} 
languages that are not or hardly spoken at Kirumba market. Braun (2019: 379) found that in trading electronic goods in local and international markets, Congolese women cultivate a large network of contacts that protect their businesses and more importantly that help them to negotiate the state's unpredictable bureaucratic rules and practices that are associated with import and export. Because this network invariably includes men in powerful positions (i.e. in police departments and government ministries), their connections easily invite one to make statements about their sexual moral. Aside from the moral judgements of these relations, there is substantial evidence of sex and bribery. These are relations and network connections that facilitate the manipulation of the network rules and conditions and serve to smoothen the flow of kayabo between places and people (Medard 2012).

\section{The local Tanzanian women traders}

The local Tanzanian women traders showed not to be eager to enter into these trade networks. One of the reasons is being too much dependency and risky contracts. The fear and the constant danger of not being able to recover the loans that are needed to make the business cycle work because of high operational and investment costs. The capital from a group of 10 Tanzanian women traders we interviewed ranged from TShs. 40,000 to $1,500,000$ (US\$17-US\$ 660). Only two had a capital worth of over TShs. 500,000 (US\$220). Table 2 contains data on the capital assets of several local Tanzanian traders. This was extremely low compared with the DRC women (see Table 1). Five of them were married, two divorced and three were single mothers. They managed to raise their capital from sources with limited financial backing: from self-help groups, village community banks, credit associations, friends, and/or family members. These women affirmed that it was difficult to be away from home for a long time and they had no holidays since forgoing working would imply a lack of food to their children and family. Taking care of food for the family is considered by them a woman's task along with the social obligations of household and family which continue to inhabit their active participation in the fish trade in similar ways and intensity as their DRC counterparts. They often combine multiple livelihood activities throughout the course of the year. They are involved in vending food; selling second-hand clothes, charcoal, fresh vegetables, fruits and firewood as well as farming; and other petty businesses.

This group of women traders avoid the relationships of dependency on a small circle of rich businessmen that otherwise characterize the Nile perch trade. This could be interpreted as an expression of 'everyday form of resistance' (Scott 1985). They rather prefer to keep their businesses small and build their trade network on traditional networks they rely on such as ethnicity, friendship, kinship relations, and family attachments (see also Bradford and Katikiro 2019; Long 1972; Tassi 2017). However, Medard et al. (2015:181) showed some local women traders also interacted with camp owners, supervisors, and crew in legal and illegal gears. They resort to maintaining sexual relations and social ties as a means to secure access to fish which they then can trade themselves. Men on the other hand, having left their wives far from the fishing camps, also engage from their part socially and sexually with women to create stability in their fishing camps an environment in which they can be treated as 'husband' to maintain discipline as a result of the influx of many women in islands and mainland fishing communities (Medard et al. 2015:76).

At Kirumba, the local women traders also sell dagaa in both local and more distant domestic markets (Hofmann 2011; Medard et al. 2015). Dagaa is attractive to them as it is easily divisible, the trade measurements are flexible (e.g. a heap, tin, sack, and kilogramme), and because it is affordable food to various income groups. Local women rely more on trading dagaa than Nile perch as the export processing factories sold everything from Nile perch - the fillets, fish maws, offcuts, belly flaps, fats, and skin. The other byproducts (such as the skeleton, fins, fish heads, and fish offals) were sold to wholesale buyers who process these and sell them on to DRC traders. Local women traders strive for the hard to get Nile perch fish from cheap and prohibited fishing gear-notably, beach seines and small size gillnets. Such illegal gears are often set by fishers at night and in isolated places so that they are harder to detect by authorities. Local women and other traders waiting for fish move from seine to seine, helping to haul them and, when the catch is in, they negotiate prices. Women engage in this illegal trade because prices are lower compared with the fish caught by the official gear whose operational and labour costs for the seine pullers are much higher. Not only that the illegal beach seine is set and hauled frequently overnight with less negotiation time. Nevertheless, women have to compete for fish with bicycle traders, agents of export processing factories, local cold storage fish dealers, and other fish traders (Medard 2012; Medard et al. 2016).

Some local women work as processors and traders of Nile perch fish heads, fins, offal, and skeletons at Kirumba and other sites. In general, livelihood diversification is an important aspect of the strategies of this category of local traders and was far more common amongst women than men. This group has over the years grown in size and their networks are more fluid than other networks. Competition, poverty, a feeling of inferiority, and catch variability affect their businesses and make them quite vulnerable to rapid network changes, competition, and shocks in supply. 


\section{Conclusions}

This paper examined the strategies of women fish traders from Tanzania and DRC competing for fish and capital to trade. They managed to enter a new trade niche that is constructed around the by-products of the Nile perch industry: kayabo. We situated their ways and strategies to operate in this niche against the background of the structural changes in the Nile perch fishing networks. The development and expansion of industrial fisheries in Tanzania have initiated major changes. At the more general level, Lake Victoria's fishing and kayabo trade, in particular, are structurally constrained by declining fish stocks (and sizes) which gives rise to increased competition in fishing and trading. The Lake Victoria fishing industry has gradually become an arena of intense struggle where women, particularly local Tanzanian women, have been increasingly squeezed out by a combination of structural changes (a new physical market, new products, new trading destinations, new actors and networks) and increased competition from the DRC traders for regional markets. It is evident that the introduction of Nile perch initiated new relationships and connections which redefined the marketing landscape through the emergence of new sets of social relations and practices. The following quote from an interview with Bibi Meng'wa, a 90-year-old woman (Medard et al. 2015:76), captures some of the transformations in Lake Victoria and its consequences for women.

The fish trade has changed because of Nile Perch, a newly introduced fish whose markets are in Europe. Trade is now done through personal contacts....you need to be at the beach all the time to show your presence. As committed mothers and old people we are totally excluded..... Today's trade is impossible without fraud, aggression, theft and sex and it traps many.

The trade networks have over time become less poly-centric in their organization, more restrictive, and less fluid and transparent with power increasingly concentrated in a few hands, notably that of wealthy male businessmen. Their power manifests at different levels. At Kirumba, they hold power over a large network of people through their control over most of the capital that flows in the market. They exert influence in the network's nodes and not just in the market, but also in fishing camps, landing sites, transport hubs, and governance systems. They acquired over time the means to mobilize actors and resources to influence and shape the kayabo business through bribing, friendship, and family affiliation. All these relationships strengthen the ability of traders to shape and manipulate the kayabo business in their favour.

The fishing business has attracted over time a range of new actors (i.e. fish brokers, factory owners and managers, truck brokers, fish collectors, agents, and sub-agents). The industry provided in this way a substantial number of people with the means to make a living on the shores of Lake Victoria. Their roles are, however, not fixed but are continuously evolving. Competition between and amongst them has increased and the new actors are vying for strategic control over the production, trading, and distribution networks that together constitute the core of the fish networks. Congolese women traders, through manipulation, bribery, and building alliances with influential brokers managed to manipulate the network rules and regulations to smoothen their control over the flow of kayabo between places and people. They manoeuvred themselves into positions from which they remain in business and derive benefits and revenues the regional market has to offer. Some of them accumulated substantial wealth and became prominent traders in a market that is otherwise dominated by males. Yet, their position in the kayabo trade network is neither based on kinship or ethnicity, nor on the capital they can invest in the trade or the relationships with fishing camps. Through forging alliances and maintaining good connections with strategic network actors, they have privileged access to information about the market and knowing whom, how, when, and where to get the fish. The greatest risk for DRC women is that they will become dependent on a single actor in the network. This may lead to considerable pressure on their business lives and forcing them to travel to remote islands which they find difficult and risky to deal with.

Their willingness to take risks, however, has strengthened their positions vis à vis Tanzanian women traders who as a result have been pushed to the margins of the trade in kayabo and other fish species. Although there are opportunities for them to get involved in the kayabo trade, their entry is limited by the way the fish trade and the fishing economy is organized. In contrast to most DRC women traders, the biggest challenge of the local Tanzanian women traders is finding enough capital to support their business and thereby their families. To them, access to cash makes the difference between failure and success of their trading business. A key point to reiterate is that the local women traders struggle over fish and capital with other women traders, notably those from DRC but also with men. There is little opportunity for women to hold managerial or decision-making positions in the cooperatives and continued efforts will be needed to address this institutional gender imbalance. The factors that limit local women's active participation in the more lucrative elements of the kayabo trade are their restricted access to fish and capital and networks. Credit facilities, specifically targeted at women, could help to begin to address this problem.

Interestingly women from both DRC and Tanzania share similar reasons for getting involved in the fish trade. Both need to complement their families' income and food security, keep their children in school, gain economic independence, and improve their welfare and social position. They are equally afflicted by similar household problems: husbands' 
abandoning them and their children, an increase in polygamous practices, and men's increase in consumption of alcohol. It was also interesting to note that these conditions contributed to increasing not only female solidarity and mutual support, but also competition amongst and between themselves as well as with men. This message was clearly conveyed in the focus group discussions in Kirumba market in 2010.

Acknowledgements This work draws on $\mathrm{PhD}$ research that was part of the integrated project "Disentangling Social and Ecological Drivers of Ecosystem changes on L. Victoria, Tanzania (SEDEC)", supported by the Netherlands Organization for Scientific Research (NWO WOTRO, a science for global development) grant W01.65.304.00. The article would have been impossible without the commitment of several actors from Lake Victoria.

Open Access This article is distributed under the terms of the Creative Commons Attribution 4.0 International License (http:// creativecommons.org/licenses/by/4.0/), which permits unrestricted use, distribution, and reproduction in any medium, provided you give appropriate credit to the original author(s) and the source, provide a link to the Creative Commons license, and indicate if changes were made.

\section{References}

Béné, C., and S. Merten. 2008. Women and fish-for-sex: Transactional sex, HIV/AIDS and gender in African fisheries. World Development 36 (5): 875-899. https://doi.org/10.1016/j.worlddev.2007.05.010.

Bradford, K., and R. Katikiro. 2019. Fighting the tides: A review of gender and fisheries in Tanzania. Fisheries Research 21: 79-88. https://doi.org/10.1016/j.fishres.2019.04.003.

Braun, L.N. 2019. Wondering women: The work of Congolese transactional traders. Africa 89 (2): 378-397. https://doi.org/10.1017/ S0001972019000135.

Ensminger, J. 1992. Making a market: The institutional transformation of an African society. Cambridge: Cambridge University Press.

Frangoudes, K., and S. Gerrard. 2018. (En)Gendering change in smallscale fisheries and fishing communities in a globalized world. Maritime Studies 17 (2): 117-124. https://doi.org/10.1007/s40152018-0113-9.

Gibbon, P. 1997. Of saviours and punks: The political economy of the Nile perch marketing chain in Tanzania. Working Paper 97.3. Danish Institute for International Studies, Centre for Development Research. 115pp.

GIZ and LVFO 2018. Responsible Fisheries Business Chain Project for the Value Chain Analysis of Nile Perch maws trade in East Africa. Deutsche GesellschaftfürInternationale Zusammenarbeit and Lake Victoria Fisheries Organization. GIZ contract no 8328557. 85pp.

Goldschmidt, T. 1998. Darwin's dreampond: Drama in Lake Victoria. Cambridge: MA: MIT Press.

Handschuch, C., and M. Wollni. 2016. Traditional food crop marketing in sub-Saharan Africa: Does gender matter? Journal of Development Studies 52 (3): 343-359.

Hofmann, A, 2011.Social networks and power relations in the Dagaa business in Mwanza, Tanzania- Dagaa Business between Collective Action and Individual Operation. Unpublished MasterThesis, Wageningen University, Law and Governance Group.

Hyden, G. 1975. Ujamaa, villagisation and rural development in Tanzania. Development and Policy Review 8 (1): 53-72.

Kudhongania, A., and A. Cordone. 1974. Batho-spatial distribution patterns and biomass estimate of the major demersal fishes in Lake
Victoria. African Journal of Tropical Hydrobiology and Fisheries 3 (1): 15-31.

Long, N. 1972. Kinship and associational networks among transporters in rural Peru: The problem of the "local" and the "cosmopolitan" entrepreneur, seminar series: Kinship and Social Networks in Latin America. Institute of Latin American Studies: London University.

Long, N. 2001. Development sociology: Actor perspectives. London: Routledge.

Long, N. 2008. Resistance, agency, and counterwork: A theoretical positioning. In The fight over food: Producers, consumers, and activists challenge the global food system, ed. W. Wright and G. Middendorf, 69-90. Pennsylvania: The Pennsylvania State University Press.

Lowen, M. 2014. Kenya's battle to end 'sex for fish' trade, BBC News for Africa. Western Kenya: Lake Victoria.

LVFO. 2007. Regional plan of action for the management of fishing capacity in Lake Victoria (RPOA-capacity); LVFO, Jinja.29pp.

LVFO//EAC. 2017. Fisheries management plan III (FMP III) for Lake Victoria fisheries 2016-2020. $42 \mathrm{pp}$.

Lwenya, C., and E. Yongo. 2012. The fisherman's wife: Vulnerabilities and strategies in the local economy; the case of Lake Victoria, Kenya, Signs, 37(3): 566-573.

Medard, M. 2003. The Nile Perch processing industry in Tanzania: Trends, issues and developments. The African Journal of Tropical Hydrobiology and Fisheries 10 (1): 71-88.

Medard, M. 2012. Relations between people relations between things: Gendered investment and the case of Lake Victoria fishery, Tanzania. Signs 37 (3): 555-566.

Medard, M. 2015. A social analysis of contested fishing practices in Lake Victoria, 278 pp. The Netherlands: Wageningen University https:// edepot.wur.nl/338839.

Medard, M., P. Hebinck, and H. van Dijk. 2015. In the shadow of global markets: Fish markets in Mwanza, Tanzania. In The Construction of New Markets and Rural Development, ed. P. Hebinck, J.D. van der Ploeg, and S. Schneider, 168-190. London: Routledge.

Medard, M., P. Hebinck, H. van Dijk, and Kim Geheb. 2016. Governance in a beach seine fishery: a case study from Lake Victoria, Tanzania. Maritime Studies 15: 11. https://doi.org/10.1186/s40152-016-0051-3.

Mills, S. 1995. Feminist stylistics. London: Routledge.

Mitchell, C.J. 1974. Social networks. Annual Review of Anthropology 3: 279-299.

Mkumbo, O.C. (2012). The fisheries of Lake Victoria in their broader socio-ecological context. Lake Victoria Fisheries Organization. (LVFO) Jinja, Uganda. Paper Presented at Socio-Ecological Drivers for Ecosystem Changes (SEDEC) Symposium, Wageningen University, The Netherlands. 05 October 2012. 39 pp.

Moore, H. 1988. Feminism and anthropology. Cambridge: Polity Press.

Moore, H. 1994. A passion for difference. Cambridge: Polity Press.

Murdoch, J. 2001. Ecologisingsociology: Actor-network theory, coconstructionism and the problem of human exceptionalism. Sociology - The Journal of the British Sociological Association 35 (1): $111-133$.

Ostrom, E. 1990. Governing the commons: The evolution of institutions for collective action. Cambridge: Cambridge University Press.

Pype, K. 2012. The making of the Pentecostal melodrama: Religion, media, and gender in Kinshasa. Oxford: Berghahn Books.

Raikes, P. 1975. Ujamaa and rural socialism. Review of African Political Economy 2 (3): 33-52.

Ribot, J. 1998. Theorizing access: Forest profits along Senegal's charcoal commodity chain. Development and Change 29 (2): 307-341.

Ribot, J., and N. Peluso. 2003. A theory of access. Rural Sociology 68 (2): 153-181.

Roberts, B. 1994. Informal economy and family strategies. International Journal of Urban and Regional Research 18 (1): 6-23.

Saunders, M., Ph. Lewis, and A. Thornhill. 2009. Research methods for business students. Fifth ed. Edinburgh Gate: Pearson Education Limited. 
Schnegg, M., and H. Lang. 2002. Netzwerkanalyse. Einepraxis orientierteEinführung. Methoden der Ethnographie 1 (1): 1-55.

Scott, J.C. 1985. Weapons of the weak: Everyday forms of peasant resistance. New Haven: Yale University Press.

Scott, J. 1992. Experience. In Feminists theorize the political, ed. J. Butler and J. Scott, 23-45. London: Routledge.

Seehausen, O. 1996. Lake Victoria rock cichlids: Taxonomy, ecology and distribution. Zevenhuize Verduijn Cichlids, Unpublished $\mathrm{PhD}$ Thesis. 304 pp.

Skaptadóttir, U.D. 1998. Coping with marginalization: Localization in an Icelandic fishing community. In Aarseether, A. and Baerenholdt, C. (eds.) Coping strategies in the North. Local practices in the context of global restructuring. Copenhagen: Nordic Council of Ministers.

Tassi, N. 2017. The native world-system. An ethnography of Bolivian Aymara traders in the global economy. Oxford: Oxford University Press.

URT. 2009. The Fisheries Regulations (G.N No. 308 of 28/8/2009). Government Printer. United Republic of Tanzania (URT). Dar es Salaam, Tanzania. 246 pp.

Publisher's note Springer Nature remains neutral with regard to jurisdictional claims in published maps and institutional affiliations. 